\title{
Ultrastructural Studies of the Effects of Allium sativum on Phytopathogenic Fungi in vitro
}

\author{
Alberto Bianchi, Dipartimento di Biologia Evolutiva e Funzionale, viale delle Scienze, 43100 Parma; Alessandra \\ Zambonelli and Aldo Zechini D'Aulerio, Dipartimento di Protezione e Valorizzazione Agroalimentare, via Filippo \\ Re 8, 40126 Bologna; and Franco Bellesia, Dipartimento di Chimica, via Campi 183, 41100 Modena
}

\begin{abstract}
Bianchi, A., Zambonelli, A., Zechini D’Aulerio, A., and Bellesia, F. 1997. Ultrastructural studies of the effects of Allium sativum on phytopathogenic fungi in vitro. Plant Dis. 81:1241-1246.

A study was made of the effects of garlic on the development of mycelium in the following phytopathogenic fungi: Fusarium solani (Mart.) Sacc., Rhizoctonia solani Kühn, Pythium ultimum Trow var. ultimum, and Colletotrichum lindemuthianum (Sacc. and Magnus) Briosi and Cav. A suspension of micronized garlic powder, which has volatile organic compounds mainly consisting of linear chain aldehydes, allyl sulfides and disulfides, was used for the trials. Mycelial development of the fungi was strongly inhibited at the maximum concentration of the aqueous extract tested $(100 \mathrm{ml} / \mathrm{liter})$; however only the growth of $P$. ultimum var. ultimum was entirely blocked. Transmission and scanning electron microscopy revealed cytomorphological alterations of the hyphae treated with garlic. $R$. solani and $C$. lindemuthianum hyphae appeared especially collapsed, while those of $F$. solani were less damaged, although thinner than the control hyphae. A general increase in vacuolization was also observed, with consequent reduction in the cytoplasm of the treated fungal cells. $R$. solani also revealed a thickening of the cell wall, whereas $C$. lindemuthianum revealed a singular accumulation of osmiophil bodies immediately under the cell membrane.
\end{abstract}

The use of natural products for the control of fungal diseases in plants is considered an interesting alternative to synthetic fungicides due to their lower negative impact on the environment (2). Among the natural fungicidal substances, garlic extract has been found to be active in various trials in vitro $(12,14,15)$ and, to a lesser degree, in vivo $(13,18)$. However, little is known about the alterations caused by this product on fungi, although studies have been carried out on the cytomorphological alterations caused by chemical product (5) and other kinds of natural products, in particular essential oils (17).

The purpose of this study was to assess the action of garlic on the ultrastructure of fungal cells of some phytopathogenic fungi.

\section{MATERIALS AND METHODS}

Determination of volatile compounds. A suspension of micronized garlic powder $(129 \mathrm{mg})$ in distilled water $(250 \mathrm{ml})$, with the addition of $25 \mu \mathrm{l}$ of the internal standard solution (chlorobenzene in water, 5 $\mu \mathrm{l} /$ liter), was flushed with helium (high grade purity, $20 \mathrm{ml} / \mathrm{min}$ ) at $80^{\circ} \mathrm{C}$ for 40

Corresponding author: A. Zambonelli

E mail: zambonel@pop.agrsci.unibo.it

Accepted for publication 7 July 1997.

Publication no. D-1997-0908-02R

(C) 1997 The American Phytopathological Society min. The volatile organic compounds were absorbed into a Chrompack Carbotrap 300 trap and transferred by means of a Chrompack Purge and Trap Injector into a Hewlett Packard GC-MS, model 5989A MS Engine, equipped with a SE54 column (25 $\mathrm{m}$ by $0.2 \mathrm{~mm}$, film thickness $0.5 \mu \mathrm{m}$ ) and helium $0.8 \mathrm{ml} / \mathrm{min}$. The column was held at $35^{\circ} \mathrm{C}$ for $2 \mathrm{~min}$ and then programmed to $250^{\circ} \mathrm{C}$ at $5^{\circ} \mathrm{C} / \mathrm{min}$. The volatile compounds were identified by comparison with library MS spectra.

Microorganisms. The pathogenic fungi used in the tests were Rhizoctonia solani Kühn, isolated from thyme seed, Pythium ultimum Trow var. ultimum (CBS collection no. 264.38), isolated from pine,
Fusarium solani (Mart.) Sacc. (CBS collection no. 231.31), isolated from oak, and Colletotrichum lindemuthianum (Sacc. \& Magnus) Briosi and Cav., isolated from bean. All the organisms were maintained on potato dextrose agar (PDA, Difco Laboratories, Detroit).

In vitro tests. The in vitro tests were carried out using a micronized garlic powder, supplied by Fitofarmaceutica Medica, Italy. This powder was prepared with Italian bulbs, dried in an oven at $35^{\circ} \mathrm{C}$ for 4 days. The dried bulbs were then pulverized with a compressed air micronizer to obtain $98 \%$ of the powder particles with a diameter of $40 \mu \mathrm{m}$. The aqueous extracts of garlic were obtained with the following procedure: $20 \mathrm{~g}$ of powder were placed in 200 $\mathrm{ml}$ of double-distilled water, shaken for 30 min, then left to decant for $24 \mathrm{~h}$ at $5^{\circ} \mathrm{C}$. The aqueous suspension obtained was first centrifuged at 2,000 rpm for $2 \mathrm{~min}$, then the supernatant was filtered twice with Whatman no. 2 filters and vacuum-filtered in sequence through 0.45 and $0.2 \mu \mathrm{m}$ Whatman cellulose membrane filters. The sterile extracts obtained were added to autoclaved PDA, $10 \mathrm{ml} / \mathrm{liter}$ and 100 $\mathrm{ml} /$ liter, and then poured into petri dishes ( $8.5 \mathrm{~cm}$ in diameter) at 40 to $45^{\circ} \mathrm{C}$. Sterile double-distilled $\mathrm{H}_{2} \mathrm{O}$ alone was added to the PDA for the control plates.

The pathogenic fungi were inoculated by placing a disk of mycelium $(0.5 \mathrm{~cm}$ in diameter), from the rim of 7-day-old cultures on PDA plates, in the center of the petri dishes. Petri dishes were kept wrapped in aluminum foil at a temperature

Table 1. Volatile compounds of the water suspension of the micronized garlic powder examined

\begin{tabular}{lrrr}
\hline $\begin{array}{l}\text { Retention } \\
\text { time (min) }\end{array}$ & Compounds & Area (\%) & ppm \\
\hline 2.576 & Methyl thiirane & 2.475 & 2.037 \\
4.326 & Allyl methyl sulfide & 2.979 & 2.451 \\
4.592 & Propenyl methyl sulfide & 3.092 & 2.545 \\
5.552 & Methyl sulfide & 2.487 & 1.764 \\
6.781 & 5-Hexenal & 0.362 & 0.298 \\
7.164 & Hexanal & 0.269 & 0.221 \\
8.675 & Chlorobenzene I.St. & 2.355 & 1.938 \\
9.206 & Allyl sulfide & 27.987 & 23.030 \\
9.582 & 2-Propyl allyl sulfide & 0.139 & 0.115 \\
11.251 & Allyl methyl disulfide & 34.411 & 28.317 \\
11.897 & Propyl methyl disulfide & 0.336 & 0.276 \\
12.480 & $N, N^{\prime}$-Dimethyl thiourea & 1.355 & 1.115 \\
12.590 & Benzaldehyde & 0.103 & 0.084 \\
12.962 & Methyl trisulfide & 0.441 & 0.363 \\
14.062 & Octanal & 0.066 & 0.055 \\
14.985 & Limonene & 0.049 & 0.041 \\
16.853 & Allyl disulfide & 11.963 & 9.845 \\
\hline
\end{tabular}


of $22 \pm 1^{\circ} \mathrm{C}$. They were inspected after 2 , $3,5,7$, and 10 days, measuring the growth of the fungal colonies along two preset diametral lines. Fungitoxicity was expressed in terms of percentage of mycelial growth inhibition and calculated according to the formula of Pandey et al. (7): $(d c-$ $d t) / d c \times 100$, where $d c=$ average diameter of fungal colony with control and $d t=$ average diameter of fungal colony with treatment.

The fungitoxicity (fungistatic/fungicidal) of garlic on the fungi tested was determined using the technique of Thompson (16) and Carta and Arras (3). The tests were repeated four times.

Electron microscopy (SEM and TEM). PDA plugs ( 1 by 1 by $0.3 \mathrm{~cm}$ ),

Table 2. Effects of garlic extract on pathogens tested

\begin{tabular}{|c|c|c|}
\hline \multirow[b]{2}{*}{ Pathogenic fungus } & \multicolumn{2}{|c|}{$\%$ Inhibition } \\
\hline & Garlic extract $(10 \mathrm{ml} /$ liter $)$ & Garlic extract $(100 \mathrm{ml} / \mathrm{liter})$ \\
\hline Fusarium solani*a & 0 & 14.5 \\
\hline Pythium ultimum var. ultimum ${ }^{* * *}$ & 0 & $100^{\mathrm{b}}$ \\
\hline Rhizoctonia solani $* *$ & 0 & 85 \\
\hline Colletotrichum lindemuthianum * & 12 & 42 \\
\hline
\end{tabular}

a Findings at the end of control growth after 10 days $(*), 5$ days (**), and 3 days (***)

b Note: fungistatic activity.

collected from the rim and from the center of the fungal colonies of the same age in the control petri dishes and in those treated with aqueous garlic extract, were prepared for scanning and transmission electron microscopy (SEM and TEM).

In SEM preparation, the samples were fixed in phosphate-buffered $3 \%$ glutaraldehyde dehydrated in graded aqueous series of acetone $(25,50,75$, and $100 \%$ ) and critical point dried with $\mathrm{CO}_{2}$ (CPD 20, Balzers Union, Milano, Italy) using acetone as the intermediate fluid. Pieces of agar were sputter-coated with gold palladium (Polaron Equipment Limited, Milano, Italy; SEM coating unit E 5000) and the fungal hyphae examined under a Philips XL-40 scanning electron microscope (Centro Grandi Strumenti, Modena University, Modena, Italy).
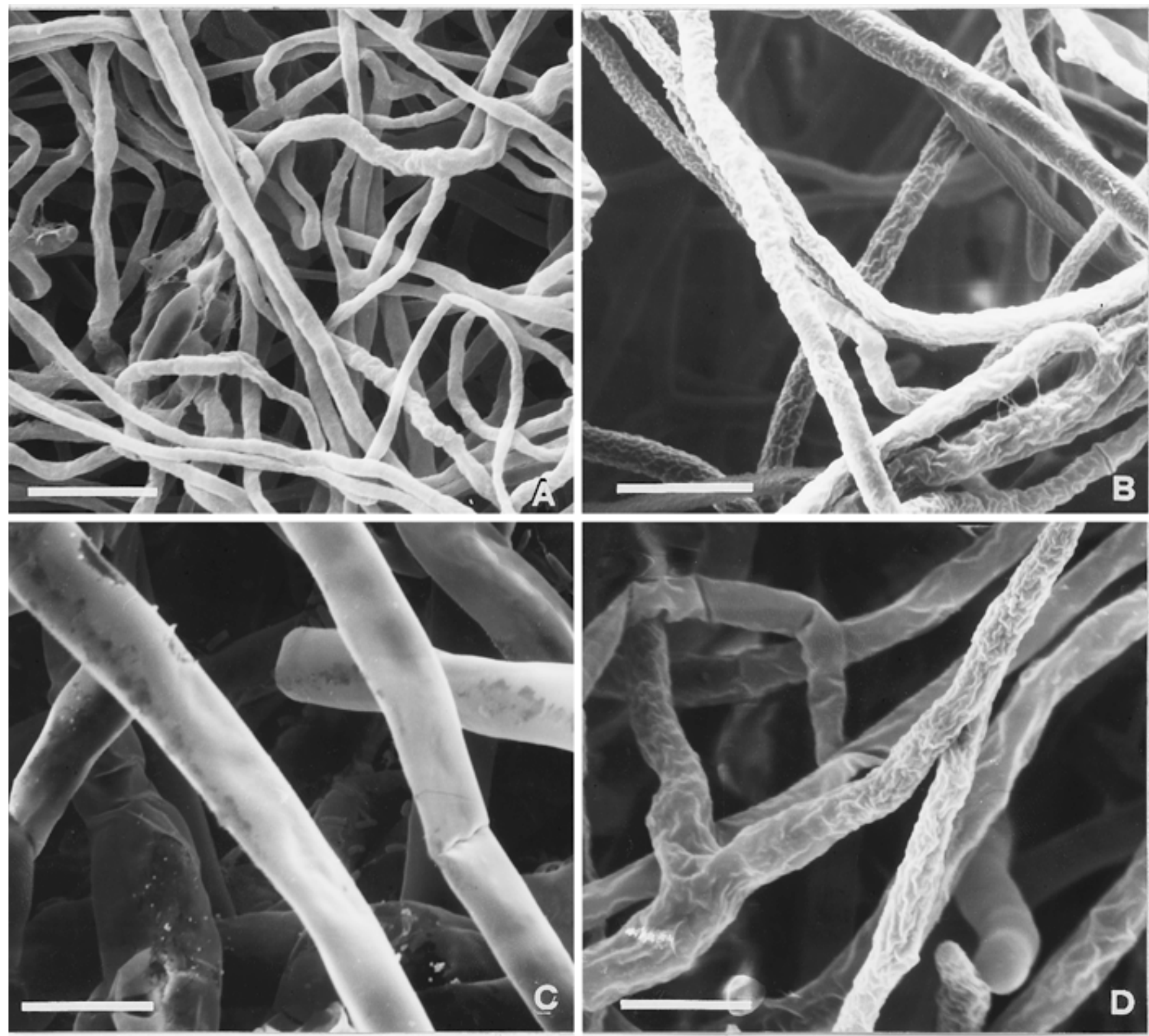

Fig. 1. Scanning electron microscopy. Colletotrichum lindemuthianum: (A) hyphae of control; (B) collapsed hyphae treated with $100 \mathrm{ml} / \mathrm{liter}$ of garlic extract. Rhizoctonia solani: (C) hyphae of control; (D) collapsed hyphae treated with $100 \mathrm{ml} /$ liter of garlic extract. Scale bars $=10 \mu \mathrm{m}$. 
In TEM preparation, the samples were fixed in phosphate-buffered 3\% glutaraldehyde, post-fixed in phosphate-buffered $1 \%$ osmium tetroxide, dehydrated in a graded aqueous series of ethanol, and embedded in
Araldite (Fluka, Milano, Italy). Ultrathin sections were cut with an LKB Ultratome, stained with uranyl acetate and lead citrate, and examined with a Seimens Elmiskop 1 A transmission electron microscope.

\section{RESULTS}

Volatile organic compounds. The volatile organic compounds mainly consisted of linear chain aldehydes (5-hexenal, hexanal, and octanal), allyl sul-
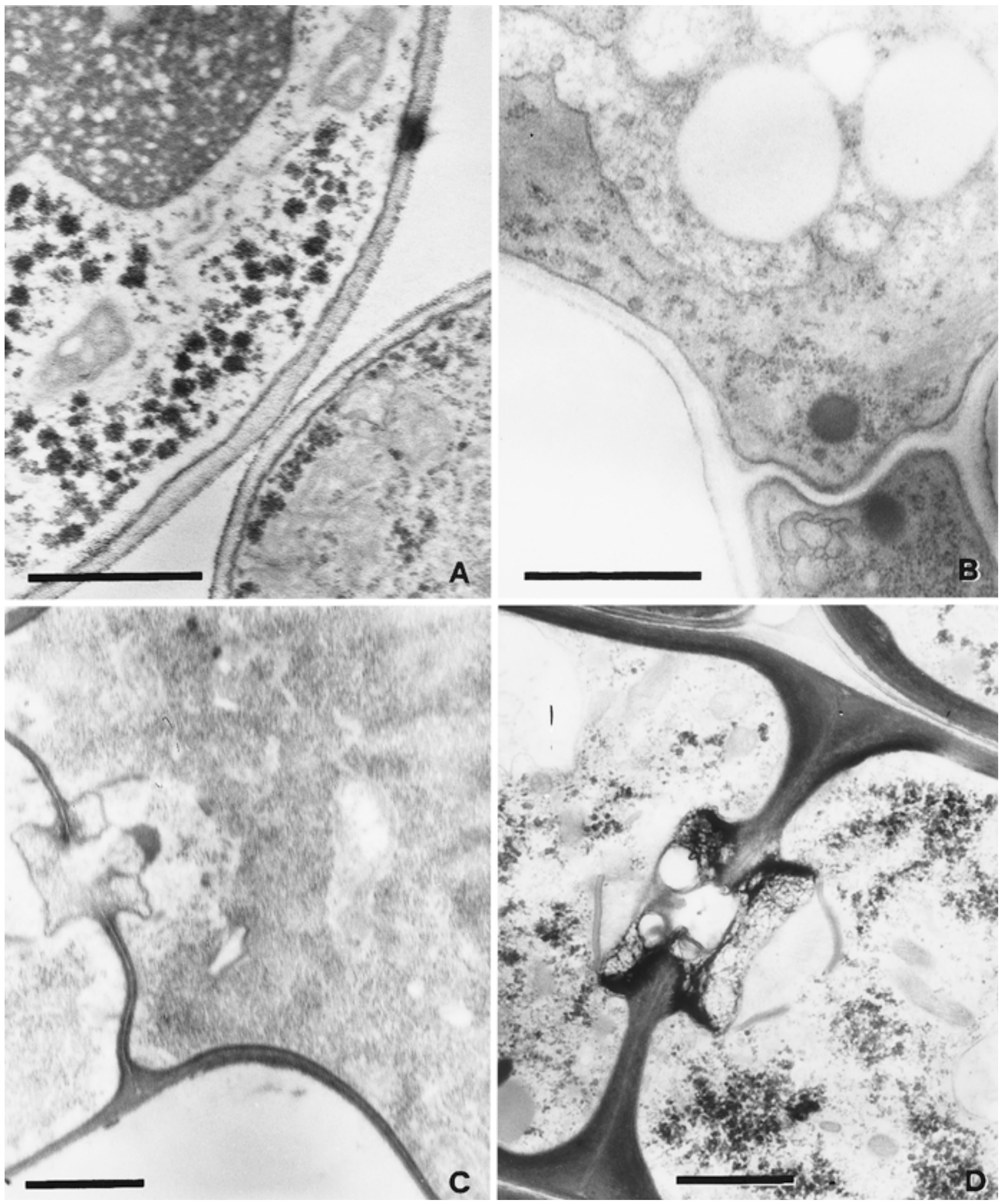

Fig. 2. Transmission electron microscopy. Fusarium solani: (A) hyphae of control; (B) hyphae of similar age of the control treated with $100 \mathrm{ml} /$ liter of garlic extract showing increase in vacuolization. Rhizoctonia solani: (C) cell wall of control; (D) strongly thickened wall of hyphae treated with 100 $\mathrm{ml} /$ liter of garlic extract with the same magnification and age as the control. Scale bars $=1 \mu \mathrm{m}$. 
fides, and disulfides (allyl disulfide and allyl methyl disulfide) (Table 1). These compounds were found to be stable a week after the preparation of the solutions.
In vitro tests. The mycelial growth of all the fungi tested was strongly inhibited with the maximum concentration of aqueous garlic extract $(100 \mathrm{ml} / \mathrm{liter})$; only the growth of $P$. ultimum var. ultimum was completely inhibited by $100 \mathrm{ml} /$ liter of garlic extract. This, however, only had a fungistatic activity, since the disk of mycelium inoculated in the treated plant began to grow again when it was transplanted to
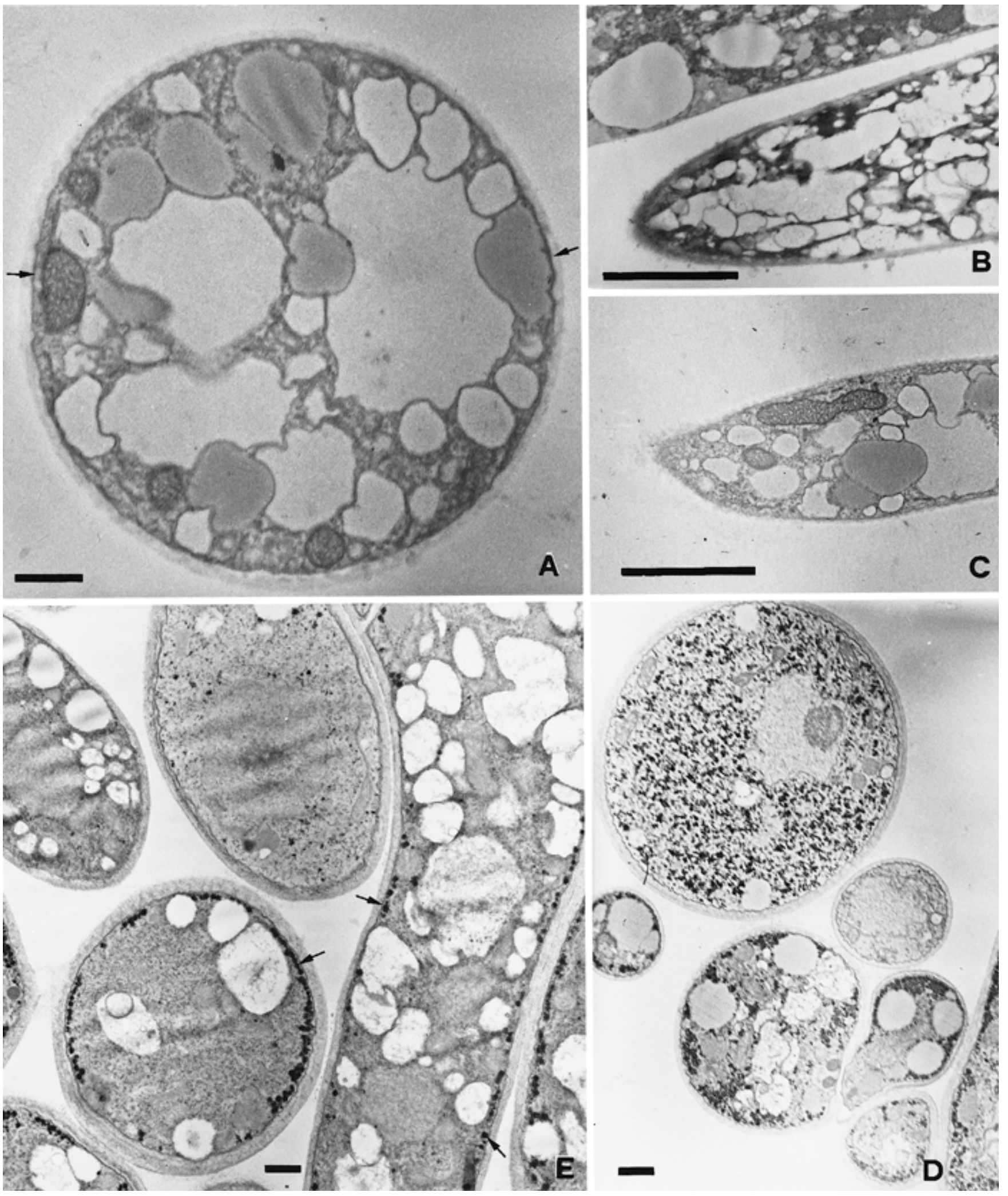

Fig. 3. Transmission electron microscopy. Pythium ultimum var. ultimum: (A) section of hypha treated with $10 \mathrm{ml} /$ liter of garlic extract, showing undulation of the cytoplasmic membrane; (B) tip of hypha of the control; (C) tip of hypha treated with $10 \mathrm{ml} /$ liter of garlic extract. The increase in the size of the vacuoles can be seen. Colletotrichum lindemuthianum: (D) hyphae of control; (E) hyphae treated with $100 \mathrm{ml} /$ liter of garlic extract showing anomalous distribution of electron dense granules. Scale bars $=1 \mu \mathrm{m}$. 
untreated agar (Table 2). The aqueous garlic extract concentration of $10 \mathrm{ml} / \mathrm{liter}$ only weakly inhibited $C$. lindemuthianum.

SEM observations. At the aqueous garlic extract concentration of $10 \mathrm{ml} / \mathrm{liter}$, only P. ultimum var. ultimum showed morphological alterations of the hypha that appeared collapsed. At the concentration of $100 \mathrm{ml} /$ liter of extract, the hyphae of $R$. solani and $C$. lindemuthianum were also seriously damaged (Fig. 1A to D), while those of $F$. solani, although they did not appear collapsed, were more fragmented and had a slightly smaller diameter than the controls (mean diameter of the control, $2.15 \pm 0.58 \mu \mathrm{m}$; mean diameter of the treated hyphae, $1.41 \pm 0.36 \mu \mathrm{m})$. The treated colonies of $F$. solani and $C$. lindemuthianum also showed a greater production of conidia.

TEM observations. Alterations of the cell structure of all the fungal species treated were observed at $10 \mathrm{ml} / \mathrm{liter}$ of aqueous garlic extract, and were more marked at $100 \mathrm{ml} /$ liter. The most frequent modification found was the increase in the number and the size of the vacuoles in the cells of the same age (Figs. 2A and B, 3B and C). R. solani also showed a marked thickening in the cell walls, up to twice the size of the controls (Fig. 2C and D). P. ultimum var. ultimum, besides the increase in vacuolization, showed a strong alteration in the cytoplasmic membrane that was partially detached from the cell wall (Fig. 3A). In $C$. lindemuthianum there was a singular accumulation of osmiophil bodies immediately under the cell membrane (Fig. 3D and E).

\section{DISCUSSION}

The garlic powder used in aqueous suspension demonstrated a good antifungal activity against the pathogenic fungi tested, even if air-dehydrated garlic contained less ajoenes than fresh garlic due to the oxidation processes that occur during the drying of the bulbs. In fact, linear chain aldehydes, such as 5-hexanal, hexenal, and octanal, indicate the intervention of oxidation during drying, in contrast with high levels of volatile sulfur-reduced compounds. These are most likely released by the disproportionation of allyl sulfenyl acid (the products of the alliinase catalyzed decomposition of alliine), rather than by reduc- tion of alliicine (arising from dimerization of allyl sulfenil acid; Fig. 4).

The fungicidal activity of the micronized garlic powder tested can, however, be only partially attributed to the volatile compound it contains. In fact, the garlic powder, after extraction in soxlet with hexane to eliminate the volatile compounds, still showed a residual fungicidal activity (unpublished data). The residual activity may be attributed to the ajoenes that are thought to be one of several pharmacologically active compounds in garlic $(10,11)$.

The cytomorphological modifications, in particular the accumulation of the lipid bodies and the thickening of the cell walls, induced by the garlic extract are similar to those produced by some synthetic fungicides (5). The series of modifications induced by the garlic extract, especially on $P$. ultimum var. ultimum and $R$. solani, including the undulations of the plasmalemma, accumulation of lipidic osmiophil bodies, the thickening of the cell walls, are similar to those observed in other fungal species during treatments with sterol-biosynthesis-inhibiting fungicides $(4,6)$.

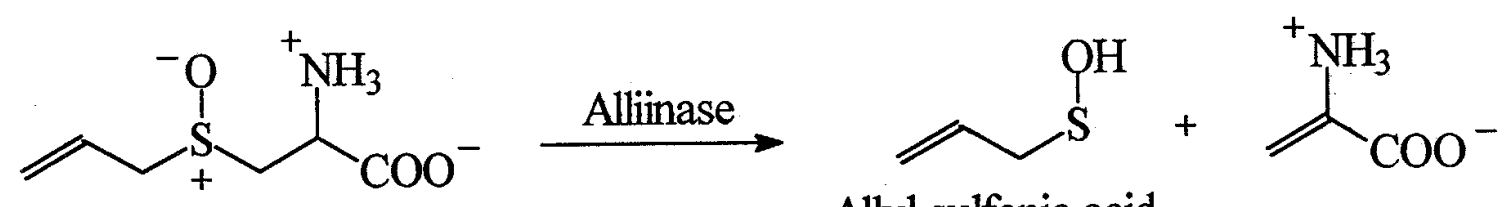

\section{Allyl sulfenic acid}
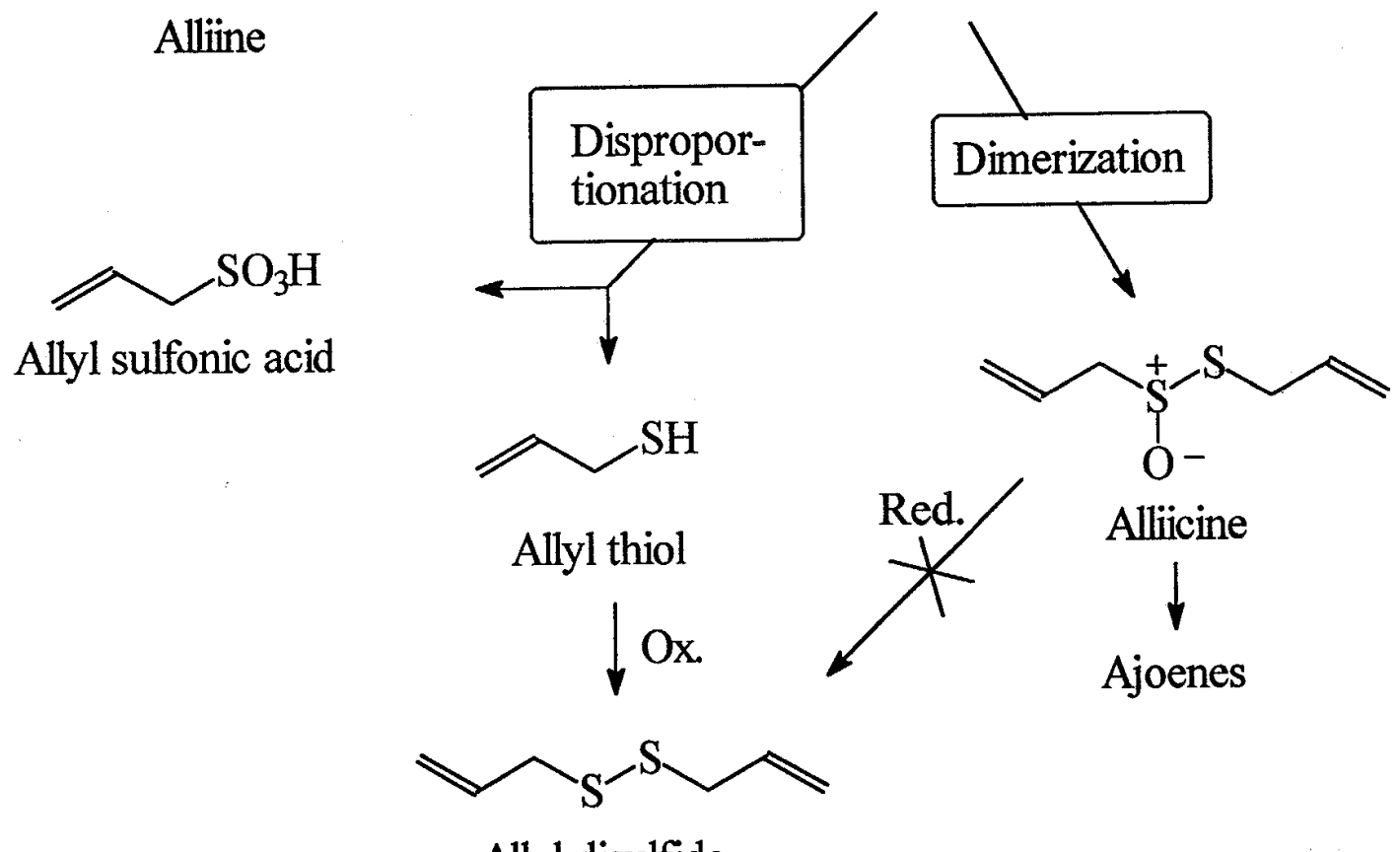

Allyl disulfide

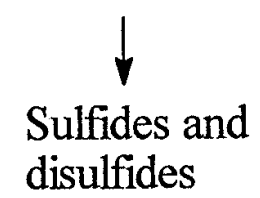

Fig. 4. Possible pathway to sulfides and disulfides in micronized garlic powder. 
Ultrastructural alterations of the cytoplasmic membrane have also been observed on some dematiaceous fungi by Sanchez Mirt et al. (8) following treatment with ajoene. Cell membrane alterations following treatment with fungitoxic products could be caused by modifications in the composition of the bilipid layer of the same membrane (9). These alterations might also, in turn, modify the activity of the membrane enzymes involved in the formation of the cell wall, causing anomalous development.

Barone and Tansey (1) suggested that the sulfur-reduced compounds present in garlic might act by binding with sulfhydrylic groups of essential amino acids, proteins, and enzymes. This study confirms this hypothesis, since the analyses of the micronized garlic powder in aqueous solution revealed the presence of numerous thioalkylating agents.

\section{ACKNOWLEDGMENT}

We thank Società d'Area tra i comuni di Brisighella, Casola Valsenio e Riolo Terme (Ravenna) for its support, and Lucia Dramis for preparation of TEM samples.

\section{LITERATURE CITED}

1. Barone, F. E., and Tansey, M. R. 1977. Isolation, purification, identification, synthesis and kinetics of activity of the anticandidal component of Allium sativum, and hypothesis for its mode of action. Mycologia 69:793-825.

2. Brunelli, A. 1995. I prodotti naturali nella lotta alle malattie fungine. La Difesa delle Piante, 18(2):57-69.

3. Carta, C., and Arras, G. 1987. Azione inibitrice in vitro di olii essenziali nei confronti di alcuni patogeni di piante ornamentali. Difesa Piante 10(1):195-202.

4. Hippe, S. 1984. Electron microscopic investigations on the cytology of Ustilago avenae influenced by the systemic fungicides triadimefon, nuarimol and imazalil-nitrate: a thin section and freeze fracture study. Pestic. Biochem. Physiol. 21:170-183.

5. Hippe, S. 1991. Influence of fungicides on fungal fine structure. Pages 317-331 in: Electron Microscopy of Plant Pathogens. K. Mendgen and D. E. Lesemann, eds. SpringerVerlag, Berlin.

6. Hippe, S., Buchenauer, H., and Grossmann, F. 1990. Einfluß von Triadimefon auf die Fein structur der Sporidien von Ustilago avenae. Z. Pflanzenkrankh. Pflanzenschutz. 87:423426.

7. Pandey, D. K., Tripathi, N. N., Tripathi, R. D., and Dixit, S. N. 1982. Fungitoxic and phytotoxic properties of essential oil of Hyptis suaveolens. Z. Pflanzenkrankh. Pflanzenschutz. 89(6):344-349.

8. Sanchez-Mirt, A., Gil, F., and Apiz-Castro, R. 1993. Efecto inhibithorio y alteraciones ultraestructurales producidas por ajoeno sobre el crecimento in vitro de los hongos dematiaceos: Cladosporium carrionii y Fonsecaea pedrosoi. Rev. Iberoam. Micol. 10(3):74-78.

9. Sancholle, M., Dargent, R., Weete, J. D, Rushing, A. E., Miller, K. S., and Montant, C. 1988. Effects of triazoles on fungi. VI. Ultrastructure of Taphrina deformans. Mycologia
80:162-175.

10. Singh, U. P., Chauhan, V. B., Wagner, K. G., and Kumar, A. 1992. Effect of ajoene, a compound derived from garlic (Allium sativun), on Phytophthora drechsleri f. sp. cajani. Mycologia 84(1):105-108.

11. Singh, U. P., Pandey, V. N., Wagner, K. G. and Sing, K. P. 1990. Antifungal activity of ajoene, a constituent of garlic (Allium sativum) L. Can. J. Bot. 68:1354-1356.

12. Singh, U. P., Pathak, K. K., Khare, M. N., and Singh, R. B. 1979. Effect of leaf extract of garlic on F. oxysporum f. sp. ciceri, Sclerotinia sclerotiorum and on gram seeds. Mycologia 71:556-563.

13. Singh, U. P., Singh H. B., and Chauhan, V. B. 1984. Effect of some fungicides, plant extracts and an oil on inoculum density of different nodal leaves of pea infected by Erysiphe polygoni. Z. Pflanzenkrankh. Pflanzenschutz. 91(1):20-26.

14. Tansey, M. R., and Appleton, J. A. 1975 Inhibition of fungal growth by garlic extract. Mycologia 67:409-413.

15. Tariq, V. N., and Magee, A. C. 1990. Effect of volatiles from garlic bulb extract on Fusarium oxysporum f. sp. lycopersici. Mycol. Res. 94(5):617-620.

16. Thompson, D. P. 1989. Fungitoxic activity of essential oil components on food storage fungi. Mycologia 81(1):151-153.

17. Zambonelli, A., Zechini D'Aulerio, A., Bianchi, A., and Albasini, A. 1996. Effects of essential oils on phytopathogenic fungi in vitro. J. Phytopathol. 144:491-494.

18. Zechini D'Aulerio, A., Zambonelli, A., and Bianchi, A. 1996. Effetto di prodotti naturali contro funghi patogeni di piante officinali. Atti Giornate Fitopatol. 2:473-478. 